假定するは正當ならん．腦下重體柄部(主として物)に於ては Prolan 檢出さるる

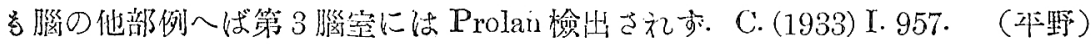

\title{
VI. 醫科器珹學
}

藥物注入器 Korrespondeuzblatt für Chirurgie-u Orthopädies-Mechanik Nr.

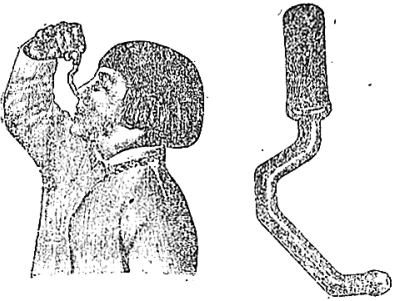

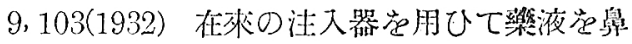

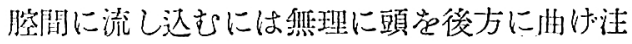
入器觉出來るだけ重值にして使用せねばなら ぬが圖の如き型であると此の不便がない，此 物は新月班に曲つた硝子管の上端にゴム球を 具へ先端は橔擥形に作り舅腔內に插入し易く してある、油状苝物に使用するときはゴム球 が硝子管より肸離すること㿥避けるため硝子管の上端にはれき鋁を附けゴム球の

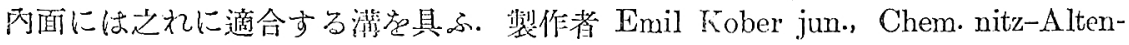
dolf.

（北川）

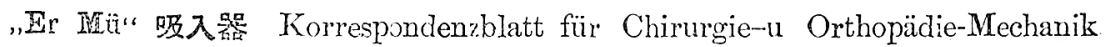

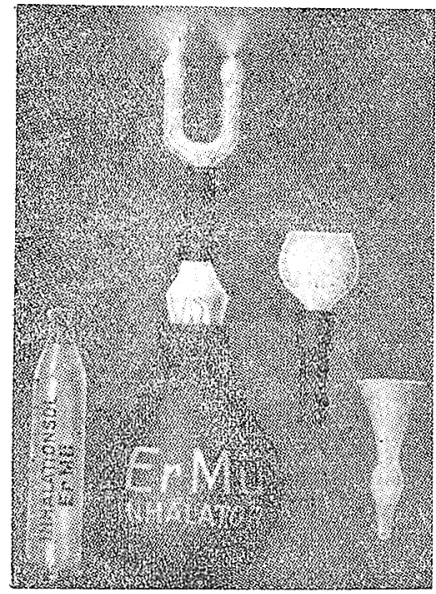
Nr. 42，448(1932) 獨逻特許 1214508 號 家庭用 携帶用の堅牢な吸入器である。本器はゴム製の球

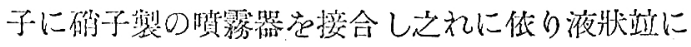

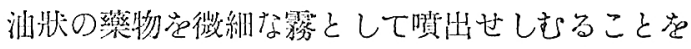

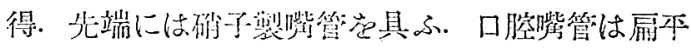

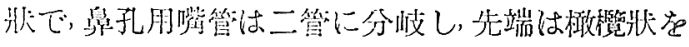

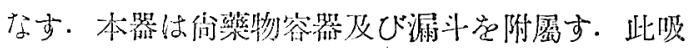
大器は挦除無易で携行にも便利である。製作者 Ernst Müller, Glasbläserei, Altenburg Thür., Zwickauer Str. 33.

(北川)

ピペット昭入裝置 Mikroe Korresondenzblatt fïr Chirurgie-u. Orthopädie-

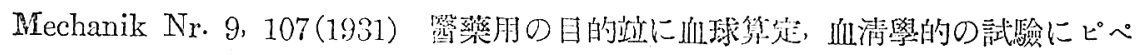

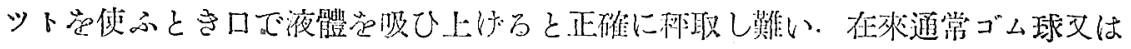
ゴム管を使用し其の繁を除いているが不純となりやすく又練猊がいる，特に血球

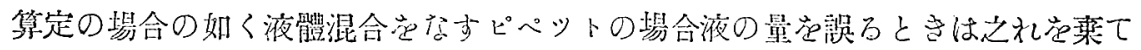




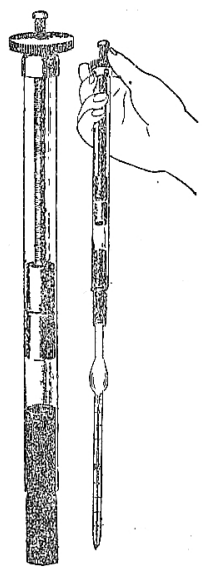

更に吸ひ上けねばならず，且操作中にピペットの目盛定正碓に

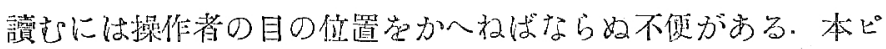
ペット吸入器は獨逸 Düsseldorf, Engeln 氏に俈り創製せられ

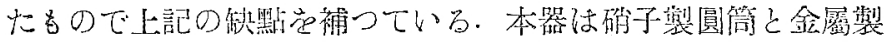
吸子とよりなり圆筒の下端にはピペットにつなぐゴム管”荧取り

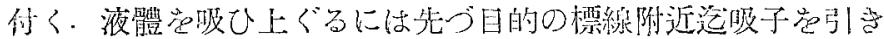

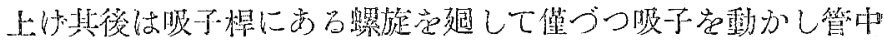

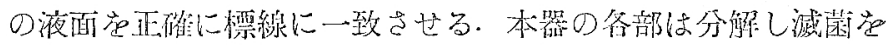

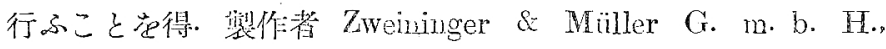
Berlin Nr. 21, Wilhelmshavener Str. 21.

(北川)

新型葴唒 Korrespondenzblatt für Chirurgie-u. Orthopädie-mechanik Nir. 43 ,

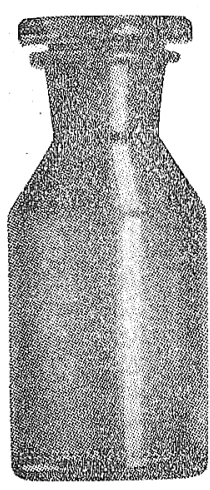

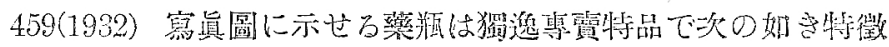

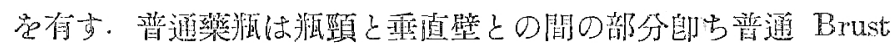

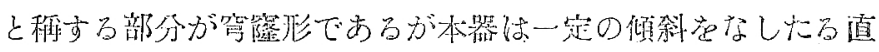

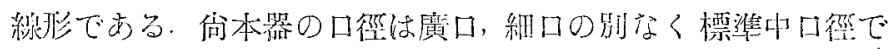

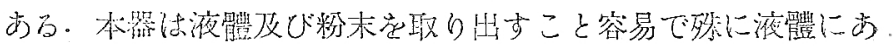

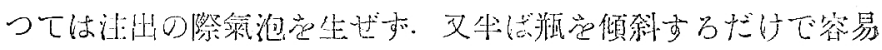

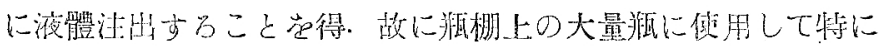

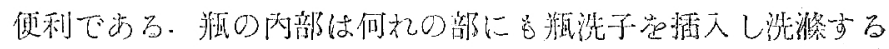
ことが出來ら. 製作者 Wagner \& Munz Inh, G. Wagner,

München 2 NW., Karlstr. 43.

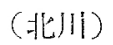

\section{VII. 蕌品製造學}

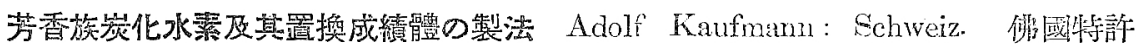

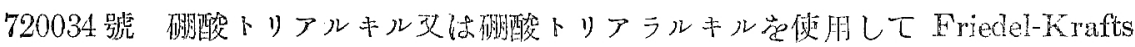

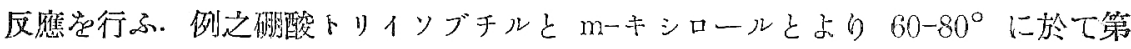

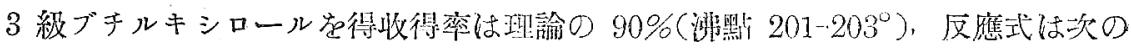
如し:

$$
\left(\mathrm{C}_{4} \mathrm{H}_{9} \mathrm{O}\right)_{3} \mathrm{~B}+3 \mathrm{C}_{3} \mathrm{H}_{13}+\mathrm{AlCl}_{3}=3 \mathrm{C}_{8} \mathrm{H}_{9} \cdot \mathrm{C}_{4} \mathrm{H}_{9}+3 \mathrm{HCl}+\mathrm{AlO}_{3} \mathrm{~B}
$$

同粶にして硯酸トリベンチルとベンゾールとからはヂフニニルヌタンとデべン 